\title{
Maxillary Alveolar Ridge Expansion with Split-Crest Technique Compared with Lateral Ridge Augmentation with Autogenous Bone Block Graft: a Systematic Review
}

\author{
Thomas Starch-Jensen ${ }^{1}$, Jonas Peter Becktor ${ }^{2}$ \\ 'Department of Oral and Maxillofacial Surgery, Aalborg University Hospital, Aalborg, Denmark. \\ ${ }^{2}$ Department of Oral and Maxillofacial Surgery and Oral Medicine, Malmö University, Malmö, Sweden.
}

\author{
Corresponding Author: \\ Thomas Starch-Jensen \\ Department of Oral and Maxillofacial Surgery \\ Aalborg University Hospital \\ 18-22 Hobrovej, DK-9000 Aalborg \\ Denmark \\ Phone: +4597662798 \\ Fax: +4597662825 \\ E-mail: thomas.jensen@rn.dk
}

\begin{abstract}
Objectives: The objective of the present systematic review was to test the hypothesis of no difference in implant treatment outcome after maxillary alveolar ridge expansion with split-crest technique compared with lateral ridge augmentation with autogenous bone block graft.

Material and Methods: A MEDLINE (PubMed), Embase and Cochrane Library search in combination with a hand-search of relevant journals was conducted. Human studies published in English until $8^{\text {th }}$ of February, 2018 were included.

Results: One comparative and four noncomparative studies fulfilled the inclusion criteria. Both treatment modalities disclosed high survival rate of implants with few complications. High survival rate of prosthesis, implant stability values, limited periimplant marginal bone loss and gain in maxillary alveolar ridge width were reported with the split-crest technique. Patientreported outcome measure and length of patient treatment time was not assessed in any of the included studies.

Conclusions: The split-crest technique seems to be useful for horizontal augmentation of maxillary alveolar deficiencies with high survival rate of prosthesis and implants. However, further long-term randomized controlled trials with larger patient sample as well as assessment of patient-reported outcome measures and patient treatment time are needed before well-defined conclusions can be provided about the two treatment modalities.
\end{abstract}

Keywords: dental implants; dentistry; guided tissue regeneration; maxilla; oral surgical procedures; review.

Accepted for publication: 23 December 2019

To cite this article:

Starch-Jensen T, Becktor JP.

Maxillary Alveolar Ridge Expansion with Split-Crest Technique Compared with Lateral Ridge Augmentation with Autogenous

Bone Block Graft: a Systematic Review

J Oral Maxillofac Res 2019;10(4):e2

URL: http://www.ejomr.org/JOMR/archives/2019/4/e2/v10n4e2.pdf

doi: $10.5037 /$ jomr.2019.10402 


\section{INTRODUCTION}

Oral rehabilitation of partially or totally edentulous patients with dental implants has become an integrated treatment modality for replacement of missing or lost teeth, with reliable long-term results [1-4]. However, placement of implants in a position for an ideal prosthetic solution is often compromised or impossible due to resorption of the alveolar ridge caused by post-extraction defects, periodontal diseases, traumatic tooth avulsion or long-term edentulism. A horizontal bone loss of the alveolar ridge varying from 29 to $63 \%$ after tooth extraction have previously been reported in a systematic review [5]. Sufficient height and width of the alveolar ridge is essential to attain the appropriate function and aesthetics of the implant-supported restorations. It has been suggested that the presence of a facial and lingual alveolar bone width of at least 1 to $1.5 \mathrm{~mm}$ around the inserted implant is prerequisite to achieve an adequate osseointegration and a predictable longterm implant treatment outcome []․ Thus, lateral augmentation of the alveolar process prior to implant placement is often necessary when the dimension of the alveolar ridge is inadequate [ $\underline{7-9}]$.

The possible anatomical situations of horizontal ridge atrophies have previously been classified in six categories and different protocols for bony reconstruction have been suggested [10]. Lateral ridge augmentation with autogenous bone block graft harvested from the ascending mandibular ramus or the iliac crest is generally considered the preferred treatment modality for lateral reconstruction of severely alveolar deficiencies and high survival rate of prosthesis and implants have been documented in systematic reviews and meta-analyses [7-9]. However, the use of autogenous bone block graft is associated with risk of donor site morbidity, an unpredictable resorption of the grafting material and prolonged patient treatment time due to an extra healing period of the grafting material [11-13]. Hence, alternative treatment strategies and techniques have been proposed for horizontal reconstruction of alveolar deficiencies involving the split-crest technique, ridge expansion and guided bone regeneration with particulated autogenous bone graft in combination with bone substitutes to diminish postsurgical morbidity and shortens patient treatment time [ㅁ, $14-17]$.

The split-crest technique in conjunction with immediate implant placement involves splitting the alveolar ridge longitudinally in two parts using chisels, piezoelectric surgery or oscillating saws. The buccal cortical bone plate is gently separated from the bone marrow and displaced in a labial direction to increase the alveolar ridge width to enable insertion of implants with an appropriate diameter. Particulated autogenous bone graft or a bone substitute is often packed around the inserted implants between the buccal and palatal cortical plate. Systematic reviews and meta-analyses have documented that horizontal reconstruction of alveolar deficiencies with the splitcrest technique seems to be a predictable and effective surgical technique with high implant survival rate, gain in horizontal alveolar ridge width, few biologic and technical complications $[\underline{6}, 14, \underline{15}, 17]$.

The split-crest technique have previously been compared to lateral ridge augmentation with autogenous bone block graft disclosing no significant differences in implant survival between the two treatment modalities, although the gain in alveolar ridge width was significantly higher with lateral ridge augmentation with autogenous bone block graft $[\underline{18}, \underline{19}]$. However, horizontal reconstruction of alveolar ridge deficiencies was performed in both the maxilla and mandible [19]. Hence, there is currently no consensus on the ideal surgical treatment modality for horizontal reconstruction of alveolar deficiencies in the maxilla. Moreover, implant treatment outcome including patient-reported outcome measures after maxillary alveolar ridge expansion with the split-crest technique compared with lateral ridge augmentation with autogenous bone block graft, has not yet been assessed specifically in a systematic review. Therefore, the objective of the present systematic review was to test the hypothesis of no difference in the final implant treatment outcome after maxillary alveolar ridge expansion with the split-crest technique compared with lateral ridge augmentation with autogenous bone block graft.

\section{MATERIAL AND METHODS Protocol and registration}

The present systematic review was conducted in accordance with the Preferred Reporting Items for Systematic Reviews and Meta-Analyses (PRISMA) statement for reporting systematic reviews [20]. The methods of the analysis and inclusion criteria were specified in advance and documented in a protocol. The review was registered in PROSPERO, an international prospective register of systematic reviews. Registration number: CRD42018087105.

The protocol can be accessed at:

https://www.crd.york.ac.uk/prospero/display_record. php?ID=CRD42018087105. 


\section{Focus question}

The question was developed according to the Patient, Intervention, Comparison and Outcome (PICO) framework as described in Table 1.

\section{Types of publications}

The review included studies on humans. Letters, editorials, $\mathrm{PhD}$ theses, letters to the editor, case reports, abstracts, technical reports, conference proceedings, studies on cadavers, animal or in vitro studies and literature review papers were excluded.

\section{Types of studies}

The review included randomized controlled trials, controlled clinical trials, prospective case-series and retrospective studies comparing the implant treatment outcome after maxillary alveolar ridge expansion with split-crest technique compared with lateral ridge augmentation with autogenous bone block graft. Moreover, human studies solely assessing maxillary alveolar ridge expansion with split-crest technique were also included as noncomparative studies.

\section{Types of outcome measures}

The primary outcome measures are the most important measures for evaluating of the final implant treatment outcome. Secondary outcome measures were also included in the present systematic review as surrogate measures.

The primary outcome measures included:

- Survival of prosthesis. Loss of prosthesis was defined as a total loss because of a mechanical and/or biological complication.

- Survival of implants. Loss of implants was defined as mobility of previously clinically osseointegrated implants and removal of non-mobile implants due to progressive periimplant marginal bone loss (PIMBL) and/or infection.

Moreover, the following secondary outcome measures were assessed:

- Implant stability. Estimated by magnetic resonance frequency analysis or alternative methods.

- PIMBL. Evaluated by radiographic measurements.

- Gain in maxillary alveolar ridge width. Estimated by clinical or radiographic measurements.

- Patient-reported outcome measures.

- Biologic and technical complications.

\section{Information sources}

The search strategy incorporated examinations of electronic databases, supplemented by a thorough hand-search page by page of relevant journals including "British Journal of Oral and Maxillofacial Surgery", "Clinical Implant Dentistry and Related Research", "Clinical Oral Implants Research", "European Journal of Oral Implantology", "Implant Dentistry", "International Journal of Oral and Maxillofacial Implants", "International Journal of Oral and Maxillofacial Surgery", "International Journal of Periodontics and Restorative Dentistry", "International Journal of Prosthodontics", "Journal of Clinical Periodontology", "Journal of Dental Research", "Journal of Oral Implantology", "Journal of Oral \& Maxillofacial Research", "Journal of Periodontology", "Journal of Prosthetic Dentistry", "Journal of Craniofacial Surgery", "Journal of Cranio-MaxilloFacial Surgery", "Journal of Oral and Maxillofacial Surgery", "Periodontology 2000", "Oral and Maxillofacial Surgery", "Oral Surgery Oral Medicine Oral Pathology Oral Radiology". The manual search also included the bibliographies of all articles selected for full-text screening as well as previously published reviews relevant for the present systematic review. One reviewer (T.S.-J.) performed the search.

Table 1. PICOS guidelines

\begin{tabular}{l|l}
\hline Patient and population (P) & Healthy patients with horizontal alveolar deficiencies of the maxillary alveolar ridge. \\
\hline Intervention (I) & Maxillary alveolar ridge expansion with the split-crest technique. \\
\hline Comparator or control group (C) & Lateral ridge augmentation with autogenous bone block graft. \\
\hline Outcomes (O) & $\begin{array}{l}\text { Primary outcome measures include survival of prosthesis and survival of implants. Secondary outcome } \\
\text { measures include implant stability, peri-implant marginal bone loss, gain in maxillary alveolar ridge } \\
\text { width, patient-reported outcome measures, biologic and technical complications. }\end{array}$ \\
\hline Study design (S) & $\begin{array}{l}\text { Randomized controlled trials, controlled clinical trials, prospective case-series and retrospective } \\
\text { studies comparing the split-crest technique with lateral ridge augmentation with autogenous bone } \\
\text { block graft. Moreover, human studies solely assessing the split-crest technique in the maxilla was also } \\
\text { included as noncomparative studies. }\end{array}$ \\
\hline Focused question & $\begin{array}{l}\text { Are there any differences in implant treatment outcome after maxillary alveolar ridge expansion with } \\
\text { the split-crest technique compared with lateral ridge augmentation with autogenous bone block graft? }\end{array}$ \\
\hline
\end{tabular}




\section{Search}

A MEDLINE (PubMed), Embase, and Cochrane Library search was conducted. Human studies published in English until $8^{\text {th }}$ of February, 2018 were included. Grey literature, unpublished literature as well as other databases like Scopus, Google Scholar, or Research Gate were not included in the search strategy of the present systematic review. The search strategy was performed in collaboration with a librarian and utilized a combination of Medical Subject Heading (MeSH) and free text terms. A detailed description of the search strategy is outlined in Appendices 1, 2 and 3

\section{Selection of studies}

The PRISMA flow diagram presents an overview of the selection process (Figure 1). The titles of the identified reports were initially screened. The abstract was assessed when the title indicated that the study was relevant. Full-text analysis was obtained for those with apparent relevance or when the abstract was unavailable. The references of the identified papers were cross-checked for unidentified articles. The study selection was performed by one reviewer (T.S.-J.).

\section{Study eligibility}

The inclusion criteria were developed using the PICOS guidelines (Table 1).

\section{Inclusion criteria}

The review exclusively focused on studies with horizontal reconstruction of alveolar deficiencies of the maxillary alveolar ridge with an observation period after functional implant loading of at least one year. In addition, at least five patients should be included in the study and the number of inserted implants and surgical procedures had to be clearly specified.

\section{Exclusion criteria}

The following exclusion criteria were applied: studies with an insufficient description of the numbers of

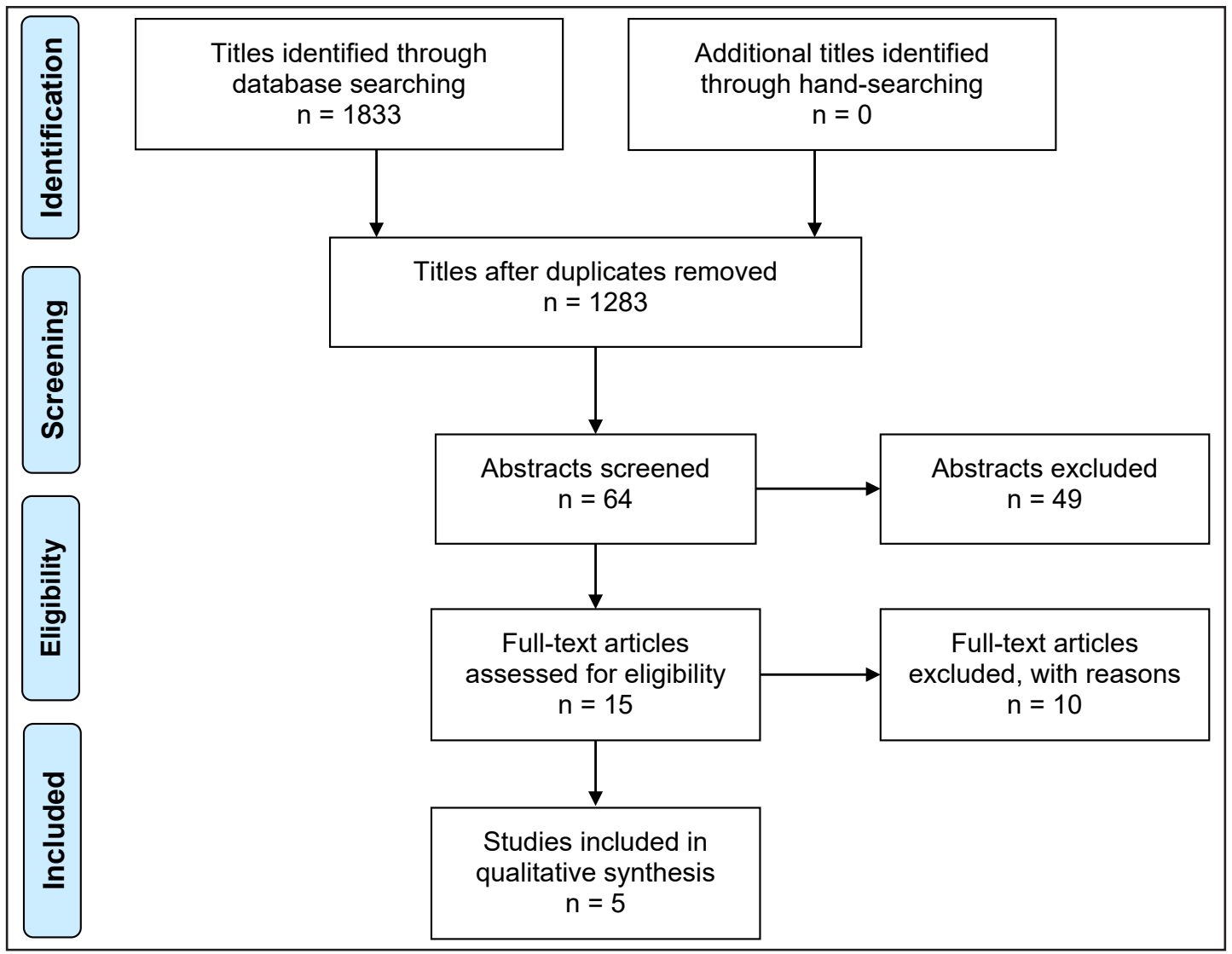

Figure 1. PRISMA flow diagram demonstrating the results of the systematic literature search.

The electronic search resulted in 1833 entries. No article was included as the result of hand-searching. Five hundred and fifty articles were excluded, because they had been retrieved in more than one search. A total of 64 abstracts were reviewed. Full-text analysis included 15 articles. Finally, five human studies were included in the present systematic review comprising one comparative study and four noncomparative studies. 
performed surgical procedures and inserted implants, length of the observation period, as well as studies involving implant placement in medically compromised patients or maxillary alveolar ridge expansion with the split-crest technique in combination with other bone augmentation procedures were excluded. Likewise, studies adding growth factors, bone morphogenetic proteins, fibrin glue or platelet-rich plasma to the grafting material, as well as studies involving osteotome-mediated maxillary alveolar ridge expansion without splitting of the narrow alveolar ridge were also excluded.

\section{Data extraction}

Data were extracted by one reviewer (T.S.-J.) according to a data-collection form ensuring systematic recording of the outcome measures. In addition, relevant characteristics of the study were recorded. The corresponding author was contacted by e-mail in the absence of important information or ambiguities.

\section{Data items}

The following items were collected from the included articles and arranged in the fields: patients, surgical procedure, implant placement, the use of graft material and membrane, implant healing time, prosthetic solution, follow-up after loading, survival of prosthesis, survival of implants, implant stability quotient (ISQ), PIMBL, gain in alveolar ridge width, biologic and technical complications, and reference.

\section{Assessment of methodological quality}

The quality assessment of the included studies was undertaken by one review author (T.S.-J.) as part of the data extraction process. A methodological quality rating system was used and the classification of the risk of bias potential for each study was based on the following five criteria:

1. Random selection between the two treatment modalities (yes/no).

2. Definition of inclusion, exclusion criteria (yes/no).

3. Report of losses to follow-up (yes/no).

4. Validated measurements (yes/no).

5. Statistical analysis (yes/no).

The studies were grouped according to:

1. Low risk of bias (plausible bias unlikely to seriously alter the results) if all above-described quality criteria were met.

2. Moderate risk of bias (plausible bias that weakens confidence in the results) when one of these criteria were not included.
3. High risk of bias (plausible bias that seriously weakens confidence in the results) when two or more criteria were missing.

\section{RESULTS \\ Study selection}

The search result is outlined in Figure 1. The electronic search resulted in 1833 entries. No article was included as the result of hand-searching. Five hundred and fifty articles were excluded, because they had been retrieved in more than one search. A total of 64 abstracts were reviewed. Full-text analysis included 15 articles. Finally, five human studies were included in the present systematic review comprising one comparative study [18] and four noncomparative studies [21-24].

\section{Exclusion of studies}

The reasons for excluding studies after full-text assessment were as follows: the study could not be excluded before meticulous reading $(n=3)$ [25-27], data was pooled from both the mandible and maxilla $(n=5)[19,28-31]$, the criterion of an observation period after functional loading of at least one year was not fulfilled $(n=1)$ [32], and the observation period was not specified $(n=1)$ [33].

\section{Study characteristics}

The included studies in the present systematic review consisted of one comparative retrospective study based on historical records [18] and four noncomparative studies involving two retrospective studies [21,22] and two prospective case-series $[23,24]$ solely assessing the split-crest technique. No information was provided in the comparative study concerning power calculation of the sample size [18]. Partially and totally edentulous patients with horizontal deficiencies of the maxillary alveolar ridge were enrolled in the included studies. The alveolar deficiency was classified according to the Cawood and Howell [34] in one study [18] and the preoperative width of the alveolar maxillary ridge was described in all the included studies $[18,21-24]$. No significant difference in patient demographics was reported in the comparative study [18]. The surgical procedure was performed by the same surgeon in the comparative study [18], whereas no information was provided about the number of surgeons involved in the noncomparative studies [2124]. The alveolar split-crest osteotomy was performed with the use of a reciprocating saw in combination 
with piezosurgical device, bone chisel and sequential osteotomes [21], diamond drill in combination with bone chisel [22], no. 64 Beaver blade in combination with bone chisel and sequential osteotomes [23], and with piezosurgical device, bone chisel and sequential osteotomes [18]. The inter-cortical space was filled with Bio-Oss ${ }^{\circledR}$ xenograft (Geistlich Pharma AG, Wolhusen, Switzerland) [18,22,24], mixture of autogenous bone graft and allogenic bovine bone graft (Laddec, Transphyto, France) [21] or Putty xenograft (Roen, Torino, Italy) [23]. The inserted implants and graft material was covered with a Bio-Gide ${ }^{\circledR}$ membrane (Geistlich Pharma AG, Wolhusen, Switzerland) [18-24], Gore Resolut (W.L. Gore \& Associates, Inc, Newark, Delaware, USA) [21] or no membrane [2,르]. Different implant systems were used including Straumann $^{\circledR}$ (Straumann AG, Basel, Switzerland) [18,22], LaserLok $^{\circledR}$ (Biohorizons, Birmingham, USA) [23] and NobelActive $^{\circledR}$ (Nobel Biocare AB, Gothenburg, Sweden) [18]. The used implant system was not specified in one study [21]. The implant stability was measured by magnetic resonance frequency analysis (Osstell, Integration Diagnostics $\mathrm{AB}$, Gothenburg, Sweden) [21] or by Nobels dynamometric tool [18]. None of the included studies provided information about training or calibration of the examiners assessing the clinical and radiographic outcome or blinded assessment. Survival of prosthesis, implant stability, PIMBL and gain in maxillary alveolar ridge width was not reported in the comparative study and patient-reported outcome measure was not reported in any of the included studies. Thus, these outcome measures are not described in the following section or outlined in Table 2 and 3 .

\section{Data synthesis}

Meta-analyses were to be conducted only if there were studies of similar comparison, reporting identical outcome measures. However, few studies were included in the present systematic review revealing considerable variations in study design, i.e. patient demographics, surgical procedure, use of different grafting material and implants, type of prosthesis, length of observation period and type of outcome measures. Therefore, a well-defined meta-analysis was not applicable.

\section{Methodological quality}

The quality of the included studies is summarized in Table 4.

\section{Outcome measures}

The results of maxillary alveolar ridge expansion with split-crest technique compared with lateral ridge augmentation with autogenous bone block graft are presented below and outlined in Table 2. This is followed by results of noncomparative studies assessing solely split-crest technique (Table 3). All the reported numerical values are presented as mean values. For each outcome measure, a summary is finally provided.

\section{Primary outcome measures \\ Survival of prosthesis}

Noncomparative studies

The 10-year survival of prosthesis after the split-crest technique was $97 \%$ [22]. Patients were rehabilitated with single crowns and/or fixed partial dentures. All prosthesis were in function at the 10-year followup examination, but abutment screw loosening had previously occurred in six patients and two single crowns had been restored due to ceramic fracture [22].

\section{Summary}

A noncomparative study demonstrated high long-term survival of prosthesis after maxillary alveolar ridge expansion with the split-crest technique.

\section{Survival of implants \\ Comparative studies}

The implant survival rate after split-crest technique was $100 \%$ after 38.3 months compared to $92.9 \%$ after lateral ridge augmentation with autogenous bone block graft, after 31.6 months [18]. There was no significant difference in implant survival rate between the two treatment modalities.

\section{Noncomparative studies}

- The 10-year implant survival rate was $97 \%$ after split-crest technique in 21 patients and installation of 40 implants [22].

- The 3-year implant survival rate was $97 \%$ after split-crest technique in 13 patients and installation of 33 implants [23]].

- The 1-year implant survival rate was $97.8 \%$ after split-crest technique in 10 patients and installation of 45 implants [24].

- The implant survival rate after split-crest technique in 8 patients and installation of 33 implants was $100 \%$, after 28.3 months [21]. 
Table 2. Maxillary alveolar ridge expansion with split-crest technique compared with lateral ridge augmentation with autogenous bone block graft

\begin{tabular}{|c|c|c|c|c|c|c|c|c|c|c|c|c|c|c|c|}
\hline \multirow{3}{*}{ Study } & \multirow{3}{*}{$\begin{array}{c}\text { Year of } \\
\text { publication }\end{array}$} & \multirow{3}{*}{ Patients } & \multicolumn{6}{|c|}{ Materials and methods } & \multirow{3}{*}{$\begin{array}{c}\text { Follow-up } \\
\text { after loading } \\
\text { (months) }\end{array}$} & \multirow{2}{*}{\multicolumn{2}{|c|}{$\begin{array}{c}\text { Primary } \\
\text { outcome measures }\end{array}$}} & \multicolumn{4}{|c|}{$\begin{array}{c}\text { Secondary } \\
\text { outcome measures }\end{array}$} \\
\hline & & & \multirow{2}{*}{\begin{tabular}{|l|} 
ARW \\
$(\mathbf{m m})$
\end{tabular}} & \multirow{2}{*}{$\begin{array}{c}\text { Surgical } \\
\text { procedure }\end{array}$} & \multirow{2}{*}{ Implant } & \multirow{2}{*}{$\begin{array}{c}\text { Graft } / \\
\text { membrane }\end{array}$} & \multirow{2}{*}{$\begin{array}{l}\text { Implant } \\
\text { healing }\end{array}$} & \multirow{2}{*}{$\begin{array}{c}\text { Prosthetic } \\
\text { solution }\end{array}$} & & & & \multirow{2}{*}{ IS } & \multirow{2}{*}{$\begin{array}{l}\text { PIMBL } \\
(\mathrm{mm})\end{array}$} & \multirow{2}{*}{$\begin{array}{c}\text { GARW } \\
(\mathbf{m m})\end{array}$} & \multirow{2}{*}{ BTC } \\
\hline & & & & & & & & & & Prosthesis & Implant & & & & \\
\hline \multirow[b]{2}{*}{ Altiparmak et al. [18] } & \multirow[b]{2}{*}{2017} & 24 & \multirow[b]{2}{*}{$3-4$} & Split-crest: 28 & 43 & Bio-Oss $^{\mathbb{Q}}+$ & & Fixed & 38.3 & & 100 & \multirow[b]{2}{*}{ NR } & \multirow[b]{2}{*}{ NR } & \multirow[b]{2}{*}{ NR } & Bad split: 3 \\
\hline & & 24 & & $\begin{array}{l}\text { LRA autogenous } \\
\text { bone block: } 28\end{array}$ & 42 & $\begin{array}{l}\text { Bio-Gide }{ }^{\circledR} \\
\text { membrane }\end{array}$ & 4 months & prosthesis & 31.6 & NR & 92.9 & & & & $\begin{array}{c}\text { Graft exposure: } 2 \\
\text { TRP: } 7.1 \%\end{array}$ \\
\hline
\end{tabular}

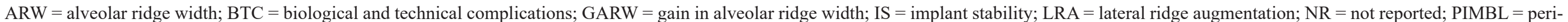
implant marginal bone loss; TRP = temporary recipient paresthesia.

Table 3. Maxillary alveolar ridge expansion with the split-crest technique

\begin{tabular}{|c|c|c|c|c|c|c|c|c|c|c|c|c|c|c|c|c|c|}
\hline \multirow{3}{*}{ Study } & \multirow{3}{*}{$\begin{array}{c}\text { Year of } \\
\text { publication }\end{array}$} & \multirow{3}{*}{ Patients } & \multicolumn{7}{|c|}{ Materials and methods } & \multirow{3}{*}{$\begin{array}{c}\text { Follow-up } \\
\text { after } \\
\text { loading } \\
\text { (months) }\end{array}$} & \multirow{2}{*}{\multicolumn{2}{|c|}{\begin{tabular}{|c|}
$\begin{array}{c}\text { Primary } \\
\text { outcome measures }\end{array}$ \\
Survival (\%) \\
\end{tabular}}} & \multicolumn{5}{|c|}{$\begin{array}{c}\text { Secondary } \\
\text { outcome measures }\end{array}$} \\
\hline & & & \multirow{2}{*}{$\begin{array}{l}\text { ARW } \\
(\mathbf{m m})\end{array}$} & \multirow{2}{*}{$\begin{array}{c}\text { Split- } \\
\text { crest }\end{array}$} & \multirow{2}{*}{ Site } & \multirow{2}{*}{ Implant } & \multirow{2}{*}{$\begin{array}{c}\text { Graft } / \\
\text { membrane }\end{array}$} & \multirow{2}{*}{$\begin{array}{c}\text { Implant } \\
\text { healing }\end{array}$} & \multirow{2}{*}{$\begin{array}{c}\text { Prosthetic } \\
\text { solution }\end{array}$} & & & & \multirow{2}{*}{ IS } & \multirow{2}{*}{\multicolumn{2}{|c|}{$\begin{array}{l}\text { PIMBL } \\
(\mathrm{mm})\end{array}$}} & \multirow{2}{*}{$\begin{array}{c}\text { GARW } \\
(\mathrm{mm})\end{array}$} & \multirow{2}{*}{ BTC } \\
\hline & & & & & & & & & & & \begin{tabular}{|l|} 
Prosthesis \\
\end{tabular} & Implant & & & & & \\
\hline \multirow{2}{*}{$\begin{array}{l}\text { González-García et } \\
\text { al. [21] }\end{array}$} & \multirow[b]{2}{*}{2011} & & \multirow[b]{2}{*}{$3-4$} & \multirow[t]{2}{*}{ 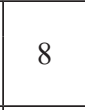 } & \multirow{2}{*}{$\begin{array}{c}\text { Anterior/ } \\
\text { posteior }\end{array}$} & \multirow[b]{2}{*}{33} & \multirow{2}{*}{\begin{tabular}{|c} 
Autogeous bone/ \\
Laddec \\
+ membrane $^{\circledR}$ \\
\end{tabular}} & \multirow[b]{2}{*}{4 months } & \multirow[b]{2}{*}{ NR } & \multirow[b]{2}{*}{28.3} & \multirow[b]{2}{*}{ NR } & \multirow[b]{2}{*}{100} & \multirow{2}{*}{$\begin{array}{l}69.5 \\
\text { ISQ }\end{array}$} & \multirow{2}{*}{\multicolumn{2}{|c|}{0.54}} & \multirow[b]{2}{*}{ NR } & \multirow[b]{2}{*}{ None } \\
\hline & & & & & & & & & & & & & & & & & \\
\hline $\begin{array}{l}\text { Garcez-Filho et al. } \\
{[22]}\end{array}$ & 2015 & 21 & $3-5$ & 26 & Posterior & 40 & Bio-Oss $^{\circledR}$ & $6-8$ weeks & $\begin{array}{c}\text { SC: } 20 \\
\text { FPD: } 19\end{array}$ & 120 & 97 & 97 & NR & \begin{tabular}{|c|}
$\begin{array}{c}6 \\
\text { months }\end{array}$ \\
0.47 \\
\end{tabular} & \begin{tabular}{|c|}
10 \\
years \\
1.93 \\
\end{tabular} & NR & $\begin{array}{l}\text { Retained screw/ } \\
\text { SC change: } 6\end{array}$ \\
\hline Santagata et al. [23] & 2015 & 13 & $4.67(3.5-7)$ & 13 & \begin{tabular}{|l|} 
Anterior/ \\
posterior
\end{tabular} & 33 & Putty $^{\circledR}$ & 4 months & NR & 36 & NR & 97 & NR & NR & & $\begin{array}{c}3.5 \\
(1.45-4.9)\end{array}$ & None \\
\hline Albanese et al. [24] & 2017 & 10 & $2.75(2.5-4)$ & 10 & Anterior & 45 & $\begin{array}{c}\text { Fresh frozen } \\
\text { bone chips }\end{array}$ & 8 months & NR & 12 & NR & 97.8 & \begin{tabular}{|c|}
35 \\
$\mathrm{Ncm}$
\end{tabular} & $1.1 \mathrm{C}$ & & 3.25 & $\begin{array}{l}\text { Oedema, } \\
\text { pain: } 9 \%\end{array}$ \\
\hline
\end{tabular}

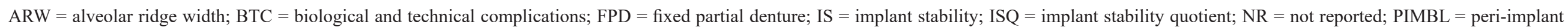
marginal bone loss; $\mathrm{SC}=$ single crowns.

Table 4. Quality assessment of the included studies for potential risk of bias

\begin{tabular}{l|c|c|c|c|c|c}
\hline \multicolumn{1}{c|}{ Study } & $\begin{array}{c}\text { Random selection } \\
\text { in the population }\end{array}$ & $\begin{array}{c}\text { Definition of inclusion } \\
\text { and exclusion criteria }\end{array}$ & $\begin{array}{c}\text { Report of losses } \\
\text { to follow-up }\end{array}$ & $\begin{array}{c}\text { Validated } \\
\text { measurements }\end{array}$ & $\begin{array}{c}\text { Statistical } \\
\text { analysis }\end{array}$ & $\begin{array}{c}\text { Risk of } \\
\text { bias }\end{array}$ \\
\hline Altiparmak et al. [18] & No & Yes & No & Yes & Yes & High \\
\hline González-García et al. [21] & No & Yes & No & Yes & No & High \\
\hline Garcez-Filho et al. [22] & No & Yes & Yes & Yes & Yes & Moderate \\
\hline Santagata et al. [23] & No & Yes & No & Yes & No & High \\
\hline Albanese et al. [24] & No & Yes & No & Yes & Yes & High \\
\hline
\end{tabular}

Each study was categorized as low, moderate or high risk of bias. 


\section{Summary}

Split-crest technique with simultaneous installation of implants demonstrated high implant survival rate with no statistically significant differences compared to lateral ridge augmentation with autogenous mandibular bone block graft and delayed implant placement.

\section{Secondary outcome measures \\ Implant stability \\ Noncomparative studies}

Osstell ISQ value measured at implant installation with split-crest technique was 69.5 [21]. Nobels dynamometric tool demonstrated that every torques at the time of implant placement was more than $35 \mathrm{Ncm}$ [24].

\section{Summary}

Noncomparative studies demonstrated high implant stability values at implant installation after maxillary alveolar ridge expansion with the split-crest technique.

\section{Peri-implant marginal bone loss}

Noncomparative studies

The 10-year PIMBL was $1.9 \mathrm{~mm}$ after split-crest technique [22]. Conventional periapical radiographs obtained six weeks after implant installation were compared to radiographs taken six months after loading and at the 10-year follow-up examination. The marginal bone level was measured mesial and distal to the implant from the implant shoulder to the first point of bone-to-implant contact [22].

The 1-year PIMBL was $1.2 \mathrm{~mm}$ after split-crest technique as evaluated by cone beam computed tomography [24].

The radiographic PIMBL after split-crest technique was $0.5 \mathrm{~mm}$. The PIMBL was assessed using panoramic radiographs obtained before implant installation and after 24 months [21].

\section{Summary}

Noncomparative studies demonstrated limited longterm PIMBL after maxillary alveolar ridge expansion with the split-crest technique.

\section{Gain in maxillary alveolar ridge width}

Noncomparative studies

Gain in maxillary alveolar ridge width was $3.5 \mathrm{~mm}$, after four months [23]. The gain in alveolar ridge width was measured with cone beam computed tomography by subtraction of the initial width of the alveolar ridge from the width at the time of abutment connection. The method and location used to estimate the gain in alveolar ridge width was not specified [23]. The intraoperative gain in alveolar ridge width was $3.3 \mathrm{~mm}$ [24]. The gain in alveolar ridge width was measured with a periodontal probe by subtraction of the initial width of the alveolar ridge from the width after the split-crest procedure [르].

\section{Summary}

Noncomparative short-term studies demonstrated an average gain in alveolar ridge width varying between 3.3 to $3.5 \mathrm{~mm}$ after maxillary alveolar ridge expansion with the split-crest technique.

\section{Biologic and technical complications \\ Comparative studies}

There was no statistically significant difference in biologic complications after split-crest technique compared to lateral ridge augmentation with autogenous bone block graft from the ascending mandibular ramus [18]. Temporary graft exposure $(2.3 \%)$, mild infection $(4.7 \%)$ and fracture of buccal bone $(7.1 \%)$ were reported after the split-crest technique, whereas temporary graft exposure $(14.3 \%)$, mild infection $(7.1 \%)$, temporary paraesthesia at the recipient site $(7.1 \%)$ and permanent graft exposure $(4.8 \%)$ was reported after lateral ridge augmentation with autogenous bone block graft. All implants were inserted as planned but the autogenous bone block graft was lost in cases where permanent graft exposure occurred [18].

\section{Noncomparative studies}

No biologic or technical complications were reported in two studies $[21,23]$. Oedema and pain was reported in $9 \%$ of the patients at suture removal, ten days after surgery [24].

Six abutment screws loosening in three patients and two ceramic fractures in one patient occurred during a ten year follow-up period [22]

\section{Summary}

Frequency of biologic and technical complications related to both treatment modalities was generally low. However, graft exposure seems to be more common after lateral ridge augmentation with 
autogenous bone block graft compared to split-crest technique.

\section{DISCUSSION}

The objective of the present systematic review was to test the hypothesis of no difference in implant treatment outcome after maxillary alveolar ridge expansion with split-crest technique compared with lateral ridge augmentation with autogenous bone block graft. One comparative retrospective study with high risk of bias [18] and four noncomparative studies with moderate [22] and high risk [21,23,24] of bias fulfilled the inclusion criteria [21-24]. No statistically significant difference in implant survival was revealed in the comparative study between split-crest technique and lateral ridge augmentation with autogenous bone block graft [18]. Noncomparative studies disclosed high survival rate of prosthesis and implants, high implant stability values, limited PIMBL and gain in maxillary alveolar ridge width after maxillary alveolar ridge expansion with the split-crest technique [2124]. Patient-reported outcome measure and length of patient treatment time was not assessed in any of the included studies. Considerable heterogeneity among the included studies prevented meta-analysis from being performed and the diversity of the used evaluation methods, small patient samples, different outcome measures and various methodological confounding factors posed serious restrictions to review the literature in a quantitative systematic manner. Hence, the conclusions drawn from the results of the present systematic review should be interpreted with extreme caution.

Lateral ridge augmentation using autogenous bone block graft is the most commonly used surgical procedure to enhance the severely atrophic alveolar ridge, and high implant survival rate has been documented in systematic reviews and metaanalysis [ $[\underline{8-10}, \underline{35-37]}$. Moreover, long-term studies assessing lateral ridge augmentation with autogenous mandibular bone block graft has disclosed an implant survival rate of 95.7 and $98.1 \%$ after 10 years $[\underline{38}, \underline{39}]$. The use of autogenous bone block graft is associated with risk of donor site morbidity, an unpredictable resorption of the grafting material and prolonged patient treatment time due to a healing period of the grafting material [11-13]. Thus, splitcrest technique with immediate implant placement has been suggested as an alternative surgical intervention for horizontal reconstruction of alveolar deficiencies to avoid bone harvesting and diminished the length of patient treatment time. However, severe alveolar deficiencies with thick cortical bone plates could jeopardize the treatment outcome following splitcrest technique since interfering cancellous bone layer is mandatory to facilitate the introduction of instruments for expansion of the alveolar ridge and ensure sufficient blood supply during the healing phase. Hence, indications for the split-crest technique or ridge expansion require a minimal horizontal width of the crest (about $3 \mathrm{~mm}$ ), while lateral ridge augmentation with autogenous bone block graft may be used also with narrower crests [40]. Furthermore, severely resorbed mandibular alveolar deficiencies with lack of elasticity or the presence of the external oblique line in the posterior region of the mandible makes the displacement and expansion of the cortical crests difficult, unless the cortical bone is completely fractured. Thus, split-crest technique is more predictable and useful for the maxilla than the mandible owing to the thinner cortical plates and softer medullary bone. In addition, a newly published systematic review assessing split-crest technique reported that the smallest gain in alveolar bone width was achieved in studies involving the mandible, whereas the highest gain in alveolar bone width was obtained in the maxilla [14]. Thus, the present systematic review exclusively included studies assessing maxillary alveolar ridge expansion, since the treatment outcome obvious differs between the jaws.

The present systematic review demonstrated high survival rate of prosthesis and implants with splitcrest technique and lateral ridge augmentation with autogenous bone block graft, which is in accordance with previous published systematic reviews and meta-analyses $[\underline{6}, \underline{8-10}, \underline{14}, \underline{15}, \underline{17}, \underline{35-37]}$. Consequently, both treatment modalities seem to be suitable for oral rehabilitation of severely alveolar maxillary deficiencies. However, a difference in implant survival of $7 \%$ is highly relevant from a clinical point of view, although no statistically significant difference was reported between the two treatment modalities.

Secondary outcomes measures of the present systematic review included implant stability, PIMBL, gain in maxillary alveolar ridge width, patientreported outcome measures, biologic and technical complications.

ISQ is measured with magnetic resonance frequency and indicates the level of implant stability and osseointegration. The scale ranges from 1 to 100 , with higher values indicating greater stability. The overall average ISQ value after osseointegration is approximately 70 and the acceptable ISQ value is estimated to be between 55 to 85 [41]. The insertion torque value is another method for indirectly 
monitoring the primary implant stability in a quantitative manner. In the present systematic review, ISQ and insertion torque measurements demonstrated satisfying primary implant stability with the split-crest technique $[\underline{21}, 24]$. However, resonance frequency analysis and insertion torque values are independent and incomparable methods of measuring primary implant stability and no general standardization in the classification of implant stability exist [42].

Several factors may influence PIMBL, including smoking habits, poor hygiene practices, systemic medical conditions, parafunctional habits, different connections between the implant and prosthesis, implant neck design, and implant surface [43-45]. A criterion of successful implant treatment is marginal bone loss of less than 1 to $1.5 \mathrm{~mm}$ during the first year after implant loading and less than $0.2 \mathrm{~mm}$ annually, which in turn corresponds to a maximum of $3.3 \mathrm{~mm}$ after 10 years $[44,45]$. Noncomparative studies included in the present systematic review meet these long-term success criterion disclosing limited PIMBL after maxillary alveolar ridge expansion with the split-crest technique $[\underline{21}, \underline{22}, 24]$. A newly publish systematic review and meta-analysis concluded that the lateral ridge augmentation with autogenous bone block graft maintain peri-implant health over time with low mucosal inflammatory changes and a relatively small incidence of peri-implant bone loss [46]. Moreover, lateral ridge augmentation with autogenous bone block graft resulted in longterm peri-implant tissue stability in periodontal compromised and healthy patients [47]. Thus, despite the small number of studies included in the present systematic review, the results indicate acceptable long-term PIMBL after split-crest technique and lateral ridge augmentation with autogenous bone block graft.

Gain in maxillary alveolar ridge width after splitcrest technique has never previously been compared with lateral ridge augmentation with autogenous bone block graft. In the present systematic review, short-term noncomparative studies demonstrated an average gain in alveolar ridge width varying between 3.25 to $3.5 \mathrm{~mm}$ after maxillary alveolar ridge expansion with split-crest technique $[\underline{23}, \underline{24}]$ Previous published systematic reviews have reported an average gain in maxillary alveolar ridge width varying between 3.2 to $4.1 \mathrm{~mm}$ after split-crest technique $[\underline{14}, \underline{15}]$. However, the data was pooled from both the maxilla and the mandible $[\underline{14}, \underline{15}]$. The gain in short-term maxillary alveolar ridge width after lateral ridge augmentation with autogenous bone block graft varies between 2.7 to $5.4 \mathrm{~mm}$ [48-50]. A newly published systematic review reported a mean horizontal gain for all particulate grafting materials of $3.7 \mathrm{~mm}$ compared to $4.5 \mathrm{~mm}$ for mixtures of particulated autogenous bone graft with allogeneic/ xenogeneic grafting material []․ Thus, lateral ridge augmentation with autogenous bone block graft or particulated autogenous bone graft in combination with different bone substitutes seems to increase gain in maxillary alveolar ridge width compared with the split-crest technique. However, long-term comparative studies are missing and the assessment of the gain in maxillary alveolar ridge width is obtained using different clinical and radiographic measurements. The conclusions may therefore be compromised by the use of different measurement techniques and further long-term randomized controlled trails should include a standardized method and three-dimensional volumetric measurements.

Frequency of biologic and technical complications with the two treatment modalities was generally low $[18,22,24]$. A nonsignificant higher percentage of graft exposure was observed after lateral ridge augmentation with autogenous bone block graft compared with split-crest technique [18]. Temporary paraesthesia, wound dehiscence with bone graft exposure, loss of bone graft and exposure of osteosynthesis screw are known complications after lateral ridge augmentation with autogenous bone block graft [51]. Hence, split-crest technique and lateral ridge augmentation with autogenous bone block graft seems to be suitable for horizontal reconstruction of severely alveolar deficiencies with few complications.

Maxillary alveolar ridge expansion with splitcrest technique and immediate implant placement compared to lateral ridge augmentation with autogenous bone block graft or mixture of particulated autogenous bone graft and bone substitutes is associated with obvious advantages for the patient, including reduced morbidity, less invasive and reduced treatment time. Consequently, a comparison of the two treatment modalities should contain an evaluation of donor site morbidity, an economic perspective, patient-reported outcome measures and length of patient treatment time. However, these aspects have not been addressed in any of the included studies.

\section{Implication for clinical practice}

Various treatment strategies have been proposed for for lateral reconstruction of severely alveolar deficiencies including split-crest technique and lateral ridge augmentation with autogenous bone block graft. Results of the present systematic review 
indicate that maxillary alveolar ridge expansion with split-crest technique and immediate implant placement is associated with obvious advantages for the patient including reduced morbidity, less invasive and reduced length of the operation time and hospitalization. However, lack of comparative longterm randomized trials assessing the two treatment modalities has made it difficult to choose the most reliable and predictable augmentation technique. Therefore, treatment of choice for prosthetic rehabilitation of the atrophic maxilla should be case specific, less invasive and achieve optimal treatment goal in the shortest period of time with less risk of biological and technical complications.

\section{Implication for research}

The results from the present systematic review are based on one comparative retrospective study with high risk of bias and non-comprarative studies including various confounding factors. Therefore, long-term randomized controlled trials assessing implant treatment outcome with the two treatment modalities including larger patient sample and standardized evaluation methods as well as an economic perspective, length of patient treatment time and patient-reported outcome measures are needed before definitive conclusions can be provided.

\section{CONCLUSIONS}

The hypothesis of no difference in the final implant treatment outcome after maxillary alveolar ridge expansion with split-crest technique compared with lateral ridge augmentation with autogenous bone block graft could neither be confirmed nor rejected due to insufficient knowledge available. Split-crest technique with immediate implant placement and lateral ridge augmentation with autogenous bone block graft disclosed high implant survival rate with few biologic and technical complications. Noncomparative studies assessing solely split-crest technique reported high survival rate of prosthesis and implants, high implant stability values, limited peri-implant marginal bone loss and gain in maxillary alveolar ridge width. Patient-reported outcome measure and length of patient treatment time was not assessed in any of the included studies. Thus, splitcrest technique seems to be suitable for horizontal augmentation of maxillary alveolar deficiencies. However, further long-term randomized controlled trials with larger patient sample as well as assessment of patient-reported outcome measures, economic perspective and patient treatment time are needed before definitive evidence-based treatment guidelines for prosthetic rehabilitation of maxillary alveolar deficiencies with dental implants can be provided.

\section{ACKNOWLEDGMENTS AND DISCLOSURE STATEMENTS}

The authors declare that there are no financial or other conflicts of interest related to this publication. There were no sources of funding for this systematic review.

\section{REFERENCES}

1. Berglundh T, Persson L, Klinge B. A systematic review of the incidence of biological and technical complications in implant dentistry reported in prospective longitudinal studies of at least 5 years. J Clin Periodontol. 2002;29 Suppl 3: 197-212; discussion 232-3. [Medline: 12787220] [doi: 10.1034/j.1600-051X.29.s3.12.x]

2. Pjetursson BE, Thoma D, Jung R, Zwahlen M, Zembic A. A systematic review of the survival and complication rates of implant-supported fixed dental prostheses (FDPs) after a mean observation period of at least 5 years. Clin Oral Implants Res. 2012 Oct;23 Suppl 6:22-38. [Medline: 23062125] [doi: 10.1111/j.1600-0501.2012.02546.x]

3. Jung RE, Zembic A, Pjetursson BE, Zwahlen M, Thoma DS. Systematic review of the survival rate and the incidence of biological, technical, and aesthetic complications of single crowns on implants reported in longitudinal studies with a mean follow-up of 5 years. Clin Oral Implants Res. 2012 Oct;23 Suppl 6:2-21. [Medline: 23062124] [doi: 10.1111/j.1600-0501.2012.02547.x]

4. Buser D, Sennerby L, De Bruyn H. Modern implant dentistry based on osseointegration: 50 years of progress, current trends and open questions. Periodontol 2000. 2017 Feb;73(1):7-21. [Medline: 28000280] [doi: 10.1111/prd.12185]

5. Tan WL, Wong TL, Wong MC, Lang NP. A systematic review of post-extractional alveolar hard and soft tissue dimensional changes in humans. Clin Oral Implants Res. 2012 Feb;23 Suppl 5:1-21. [Medline: 22211303] [doi: 10.1111/j.1600-0501.2011.02375.x]

6. Bassetti MA, Bassetti RG, Bosshardt DD. The alveolar ridge splitting/expansion technique: a systematic review. Clin Oral Implants Res. 2016 Mar;27(3):310-24. [Medline: 25586966] [doi: 10.1111/clr.12537]

7. Aludden HC, Mordenfeld A, Hallman M, Dahlin C, Jensen T. Lateral ridge augmentation with Bio-Oss alone or BioOss mixed with particulate autogenous bone graft: a systematic review. Int J Oral Maxillofac Surg. 2017 Aug;46(8): 1030-1038. [Medline: 28366452] [doi: 10.1016/j.ijom.2017.03.008] 
8. Troeltzsch M, Troeltzsch M, Kauffmann P, Gruber R, Brockmeyer P, Moser N, Rau A, Schliephake H. Clinical efficacy of grafting materials in alveolar ridge augmentation: A systematic review. J Craniomaxillofac Surg. 2016 Oct;44(10): 1618-1629. [Medline: 27622971] [doi: 10.1016/j.jems.2016.07.028]

9. Sanz-Sánchez I, Ortiz-Vigón A, Sanz-Martín I, Figuero E, Sanz M. Effectiveness of Lateral Bone Augmentation on the Alveolar Crest Dimension: A Systematic Review and Meta-analysis. J Dent Res. 2015 Sep;94(9 Suppl):128S-42S. [Medline: 26215467] [doi: 10.1177/0022034515594780]

10. Hammerle CHF, Jung RE. Ridge augmentations procedures. In: Lindhe J, Lang NP, Karring T, editors. Clinical Periodontology and Implant Dentistry. Oxford: Blackwell Munksgaard; 2008. p. 1083-98.

11. Jensen T, Schou S, Svendsen PA, Forman JL, Gundersen HJ, Terheyden H, Holmstrup P. Volumetric changes of the graft after maxillary sinus floor augmentation with Bio-Oss and autogenous bone in different ratios: a radiographic study in minipigs. Clin Oral Implants Res. 2012 Aug;23(8):902-10. [Medline: 22044477] [doi: 10.1111/j.1600-0501.2011.02245.x]

12. Johansson B, Grepe A, Wannfors K, Hirsch JM. A clinical study of changes in the volume of bone grafts in the atrophic maxilla. Dentomaxillofac Radiol. 2001 May;30(3):157-61. [Medline: 11420628] [doi: 10.1038/sj.dmfr.4600601]

13. Clavero J, Lundgren S. Ramus or chin grafts for maxillary sinus inlay and local onlay augmentation: comparison of donor site morbidity and complications. Clin Implant Dent Relat Res. 2003;5(3):154-60. [Medline: 14575631] [doi: 10.1111/j.1708-8208.2003.tb00197.x]

14. Waechter J, Leite FR, Nascimento GG, Carmo Filho LC, Faot F. The split crest technique and dental implants: a systematic review and meta-analysis. Int J Oral Maxillofac Surg. 2017 Jan;46(1):116-128. [Medline: 27639295] [doi: 10.1016/j.ijom.2016.08.017]

15. Elnayef B, Monje A, Lin GH, Gargallo-Albiol J, Chan HL, Wang HL, Hernández-Alfaro F. Alveolar ridge split on horizontal bone augmentation: a systematic review. Int J Oral Maxillofac Implants. 2015 May-Jun;30(3):596-606. [Medline: 26009911] [doi: 10.11607/jomi.4051]

16. Mordenfeld A, Aludden H, Starch-Jensen T. Lateral ridge augmentation with two different ratios of deproteinized bovine bone and autogenous bone: A 2-year follow-up of a randomized and controlled trial. Clin Implant Dent Relat Res. 2017 Oct;19(5):884-894. [Medline: 28656713] [doi: 10.1111/cid.12512]

17. Mestas G, Alarcón M, Chambrone L. Long-Term Survival Rates of Titanium Implants Placed in Expanded Alveolar Ridges Using Split Crest Procedures: A Systematic Review. Int J Oral Maxillofac Implants. 2016 May-Jun;31(3):591-9. [Medline: 27183068] [doi: 10.11607/jomi.4453]

18. Altiparmak N, Akdeniz SS, Bayram B, Gulsever S, Uckan S. Alveolar Ridge Splitting Versus Autogenous Onlay Bone Grafting: Complications and Implant Survival Rates. Implant Dent. 2017 Apr;26(2):284-287. [Medline: 28114264] [doi: 10.1097/ID.0000000000000541]

19. Gurler G, Delilbasi C, Garip H, Tufekcioglu S. Comparison of alveolar ridge splitting and autogenous onlay bone grafting to enable implant placement in patients with atrophic jaw bones. Saudi Med J. 2017 Dec;38(12):1207-1212. [Medline: 29209669] [PMC free article: 5787631] [doi: 10.15537/smj.2017.12.21462]

20. Welch V, Petticrew M, Tugwell P, Moher D, O’Neill J, Waters E, White H; PRISMA-Equity Bellagio group. PRISMAEquity 2012 extension: reporting guidelines for systematic reviews with a focus on health equity. PLoS Med. 2012;9(10):e1001333. [Medline: 23222917] [PMC free article: 3484052] [doi: 10.1371/journal.pmed.1001333]

21. González-García R, Monje F, Moreno C. Alveolar split osteotomy for the treatment of the severe narrow ridge maxillary atrophy: a modified technique. Int J Oral Maxillofac Surg. 2011 Jan;40(1):57-64. [Medline: 20729037] [doi: 10.1016/j.ijom.2010.03.030]

22. Garcez-Filho J, Tolentino L, Sukekava F, Seabra M, Cesar-Neto JB, Araújo MG. Long-term outcomes from implants installed by using split-crest technique in posterior maxillae: 10 years of follow-up. Clin Oral Implants Res. 2015 Mar;26(3):326-31. [Medline: 24438355] [doi: 10.1111/clr.12330]

23. Santagata M, Guariniello L, Tartaro G. Modified edentulous ridge expansion technique and immediate implant placement: a 3-year follow-up. J Oral Implantol. 2015 Apr;41(2):184-7. [Medline: 23641728] [doi: 10.1563/AAID-JOI-D-12-00308]

24. Albanese M, Ricciardi G, Luciano U, Donadello D, Lucchese A, Gelpi F, Zangani A, De Santis D, Rizzini A, Rossetto A, Bertossi D. Alveolar splitting with Piezosurgery ${ }^{\circledR}$, bone bank grafts and NobelActive implants as an alternative to major bone grafting for maxillary reconstruction. Minerva Stomatol. 2019 Feb;68(1):3-10. [Medline: 28677938] [doi: 10.23736/S0026-4970.17.04006-7]

25. Mounir M, Beheiri G, El-Beialy W. Assessment of marginal bone loss using full thickness versus partial thickness flaps for alveolar ridge splitting and immediate implant placement in the anterior maxilla. Int J Oral Maxillofac Surg. 2014 Nov;43(11):1373-80. [Medline: 24973295] [doi: 10.1016/j.ijom.2014.05.021]

26. Crespi R, Capparè $P$, Gherlone EF. Electrical mallet provides essential advantages in split-crest and immediate implant placement. Oral Maxillofac Surg. 2014 Mar;18(1):59-64. [Medline: 23329162] [doi: 10.1007/s10006-013-0389-2]

27. Tang YL, Yuan J, Song YL, Ma W, Chao X, Li DH. Ridge expansion alone or in combination with guided bone regeneration to facilitate implant placement in narrow alveolar ridges: a retrospective study. Clin Oral Implants Res. 2015 Feb;26(2):204-11. [Medline: 24330035] [doi: 10.1111/clr.12317]

28. Crespi R, Bruschi GB, Gastaldi G, Capparé P, Gherlone EF. Immediate Loaded Implants in Split-Crest Procedure. Clin Implant Dent Relat Res. 2015 Oct;17 Suppl 2:e692-8. [Medline: 25781900] [doi: 10.1111/cid.12316] 
29. Bruschi GB, Capparé P, Bravi F, Grande N, Gherlone E, Gastaldi G, Crespi R. Radiographic Evaluation of Crestal Bone Level in Split-Crest and Immediate Implant Placement: Minimum 5-Year Follow-up. Int J Oral Maxillofac Implants. 2017 Jan/Feb;32(1):114-120. [Medline: 28095517] [doi: 10.11607/jomi.4203]

30. Demetriades N, Park JI, Laskarides C. Alternative bone expansion technique for implant placement in atrophic edentulous maxilla and mandible. J Oral Implantol. 2011 Aug;37(4):463-71. [Medline: 20662673] [doi: 10.1563/AAID-JOI-D-10-00028]

31. Blus C, Szmukler-Moncler S, Vozza I, Rispoli L, Polastri C. Split-crest and immediate implant placement with ultrasonic bone surgery (piezosurgery): 3-year follow-up of 180 treated implant sites. Quintessence Int. 2010 Jun;41(6):463-9. [Medline: 20490388]

32. Ferrigno N, Laureti M. Surgical advantages with ITI TE implants placement in conjunction with split crest technique. 18-month results of an ongoing prospective study. Clin Oral Implants Res. 2005 Apr;16(2):147-55. [Medline: 15777323 ] [doi: 10.1111/j.1600-0501.2005.01125.x]

33. Sethi A, Kaus T. Maxillary ridge expansion with simultaneous implant placement: 5-year results of an ongoing clinical study. Int J Oral Maxillofac Implants. 2000 Jul-Aug;15(4):491-9. [Medline: 10960981]

34. Cawood JI, Howell RA. A classification of the edentulous jaws. Int J Oral Maxillofac Surg. 1988 Aug;17(4):232-6. [Medline: 3139793] [doi: 10.1016/S0901-5027(88)80047-X]

35. Esposito M, Grusovin MG, Felice P, Karatzopoulos G, Worthington HV, Coulthard P. The efficacy of horizontal and vertical bone augmentation procedures for dental implants - a Cochrane systematic review. Eur J Oral Implantol. 2009 Autumn;2(3):167-84. [Medline: 20467628]

36. Kuchler U, von Arx T. Horizontal ridge augmentation in conjunction with or prior to implant placement in the anterior maxilla: a systematic review. Int J Oral Maxillofac Implants. 2014;29 Suppl:14-24. [Medline: 24660187] [doi: 10.11607/jomi.2014suppl.g1.1]

37. Aloy-Prósper A, Peñarrocha-Oltra D, Peñarrocha-Diago M, Peñarrocha-Diago M. The outcome of intraoral onlay block bone grafts on alveolar ridge augmentations: a systematic review. Med Oral Patol Oral Cir Bucal. 2015 Mar 1;20(2): e251-8. [Medline: 25662543] [PMC free article: 4393991] [doi: 10.4317/medoral.20194]

38. Chappuis V, Cavusoglu Y, Buser D, von Arx T. Lateral Ridge Augmentation Using Autogenous Block Grafts and Guided Bone Regeneration: A 10-Year Prospective Case Series Study. Clin Implant Dent Relat Res. 2017 Feb;19(1):85-96. [Medline: 27476677] [doi: 10.1111/cid.12438]

39. Meijndert CM, Raghoebar GM, Meijndert L, Stellingsma K, Vissink A, Meijer HJ. Single implants in the aesthetic region preceded by local ridge augmentation; a 10-year randomized controlled trial. Clin Oral Implants Res. 2017 Apr;28(4): 388-395. [Medline: 26919705] [doi: 10.1111/clr.12811]

40. Fu JH, Wang HL. Horizontal bone augmentation: the decision tree. Int J Periodontics Restorative Dent. 2011 Jul-Aug; 31(4):429-36. [Medline: 21837309]

41. Sennerby L, Meredith N. Implant stability measurements using resonance frequency analysis: biological and biomechanical aspects and clinical implications. Periodontol 2000. 2008;47:51-66. [Medline: 18412573] [doi: 10.1111/j.1600-0757.2008.00267.x]

42. Lages FS, Douglas-de Oliveira DW, Costa FO. Relationship between implant stability measurements obtained by insertion torque and resonance frequency analysis: A systematic review. Clin Implant Dent Relat Res. 2018 Feb;20(1): 26-33. [Medline: 29194944] [doi: 10.1111/cid.12565]

43. Turri A, Rossetti PH, Canullo L, Grusovin MG, Dahlin C. Prevalence of Peri-implantitis in Medically Compromised Patients and Smokers: A Systematic Review. Int J Oral Maxillofac Implants. 2016 Jan-Feb;31(1):111-8. [Medline: 26800167] [doi: 10.11607/jomi.4149]

44. Albrektsson T, Zarb G, Worthington P, Eriksson AR. The long-term efficacy of currently used dental implants: a review and proposed criteria of success. Int J Oral Maxillofac Implants. 1986 Summer;1(1):11-25. [Medline: $\underline{3527955]}$

45. Laurell L, Lundgren D. Marginal bone level changes at dental implants after 5 years in function: a meta-analysis. Clin Implant Dent Relat Res. 2011 Mar;13(1):19-28. [Medline: 19681932] [doi: 10.1111/j.1708-8208.2009.00182.x]

46. Sanz-Sánchez I, Carrillo de Albornoz A, Figuero E, Schwarz F, Jung R, Sanz M, Thoma D. Effects of lateral bone augmentation procedures on peri-implant health or disease: A systematic review and meta-analysis. Clin Oral Implants Res. 2018 Mar;29 Suppl 15:18-31. [Medline: 29498126] [doi: 10.1111/clr.13126]

47. Keeve PL, Khoury F. Long-Term Results of Peri-implant Conditions in Periodontally Compromised Patients Following Lateral Bone Augmentation. Int J Oral Maxillofac Implants. 2017 Jan/Feb;32(1):137-146. [Medline: 28095518] [doi: $10.11607 /$ jomi.4880]

48. Deeb GR, Laskin DM, Deeb JG. Simultaneous Impacted Third Molar Extraction and Lateral Ramus Block Graft Harvest for Horizontal Ridge Augmentation: A Case Series. J Oral Maxillofac Surg. 2017 Mar;75(3):509-513. [Medline: 28011327] [doi: 10.1016/j.joms.2016.11.014]

49. Monje A, Monje F, Hernández-Alfaro F, Gonzalez-García R, Suárez-López del Amo F, Galindo-Moreno P, MontaneroFernández J, Wang HL. Horizontal Bone Augmentation Using Autogenous Block Grafts and Particulate Xenograft in the Severe Atrophic Maxillary Anterior Ridges: A Cone-Beam Computerized Tomography Case Series. J Oral Implantol. 2015 Jul;41 Spec No:366-71. [Medline: 24702157] [doi: 10.1563/AAID-JOI-D-13-00219] 
50. Barbu HM, Andreescu CF, Lorean A, Kolerman R, Moraru L, Mortellaro C, Mijiritsky E. Comparison of Two Techniques for Lateral Ridge Augmentation in Mandible With Ramus Block Graft. J Craniofac Surg. 2016 May;27(3):662-7. [Medline: 27092913] [doi: 10.1097/SCS.0000000000002561]

51. Peñarrocha-Diago M, Aloy-Prósper A, Peñarrocha-Oltra D, Calvo-Guirado JL, Peñarrocha-Diago M. Localized lateral alveolar ridge augmentation with block bone grafts: simultaneous versus delayed implant placement: a clinical and radiographic retrospective study. Int J Oral Maxillofac Implants. 2013 May-Jun;28(3):846-53. [Medline: 23748318] [doi: 10.11607/jomi.2964]

\section{To cite this article:}

Starch-Jensen T, Becktor JP.

Maxillary Alveolar Ridge Expansion with Split-Crest Technique Compared with Lateral Ridge Augmentation with Autogenous Bone Block Graft: a Systematic Review

J Oral Maxillofac Res 2019;10(4):e2

URL: http://www.ejomr.org/JOMR/archives/2019/4/e2/v10n4e2.pdf

doi: $10.5037 /$ jomr.2019.10402

Copyright (C) Starch-Jensen T, Becktor JP. Published in the JOURNAL OF ORAL \& MAXILLOFACIAL RESEARCH (http://www.ejomr.org), 30 December 2019.

This is an open-access article, first published in the JOURNAL OF ORAL \& MAXILLOFACIAL RESEARCH, distributed under the terms of the Creative Commons Attribution-Noncommercial-No Derivative Works 3.0 Unported License, which permits unrestricted non-commercial use, distribution, and reproduction in any medium, provided the original work and is properly cited. The copyright, license information and link to the original publication on (http://www.ejomr.org) must be included. 
Appendix 1. PubMed search until the $8^{\text {th }}$ of February, 2018

\begin{tabular}{|c|c|}
\hline Search & Query \\
\hline$\# 2$ & 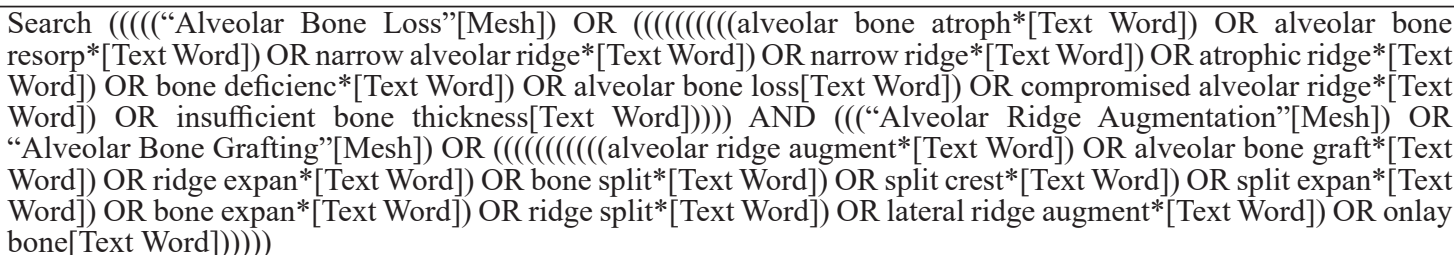 \\
\hline
\end{tabular}

Appendix 2. Embase search until the $8^{\text {th }}$ of February, 2018

\begin{tabular}{|c|c|c|}
\hline No. & Query & Results \\
\hline$\# 25$ & \#11 AND \#24 & 218 \\
\hline \#24 & $\# 12$ OR \#13 OR \#14 OR \#15 OR \#16 OR \#17 OR \#18 OR \#19 OR \#20 OR \#21 OR \#22 OR \#23 & 2099 \\
\hline \#23 & 'bone expan*' & 295 \\
\hline$\# 22$ & 'onlay bone' & 351 \\
\hline$\# 21$ & 'lateral ridge augment*' & 45 \\
\hline \#20 & 'ridge split*' & 58 \\
\hline$\# 19$ & 'split expan*' & 5 \\
\hline \#18 & 'split crest*' & 49 \\
\hline$\# 17$ & 'bone split*' & 52 \\
\hline$\# 16$ & 'ridge expan*' & 104 \\
\hline \#15 & 'alveolar bone graft*' & 628 \\
\hline \#14 & 'alveolar ridge augment*' & 689 \\
\hline \#13 & 'alveolar bone grafting'/exp & 251 \\
\hline$\# 12$ & 'alveolar ridge augmentation'/exp & 271 \\
\hline \#11 & \#1 OR \#2 OR \#3 OR \#4 OR \#5 OR \#6 OR \#7 OR \#8 OR \#9 OR \#10 & 6092 \\
\hline$\# 10$ & 'insufficient bone thickness' & 4 \\
\hline \#9 & 'compromised alveolar ridge*' & 9 \\
\hline$\# 8$ & 'alveolar bone loss' & 4893 \\
\hline$\# 7$ & 'bone deficienc*' & 545 \\
\hline \#6 & 'atrophic ridge*' & 70 \\
\hline$\# 5$ & 'narrow ridge*' & 63 \\
\hline$\# 4$ & 'narrow alveolar ridge*' & 25 \\
\hline \#3 & 'alveolar bone resorp*' & 694 \\
\hline$\# 2$ & 'alveolar bone atroph*' & 32 \\
\hline$\# 1$ & 'alveolar bone loss'/exp & 3711 \\
\hline
\end{tabular}

Appendix 3. Cochrane Library search until the $8^{\text {th }}$ of February, 2018

\begin{tabular}{l|l|c}
\hline ID & \multicolumn{1}{|c}{ Search } & Hits \\
\hline$\# 1$ & MeSH descriptor: [Alveolar Bone Loss] explode all trees & 1111 \\
\hline$\# 2$ & alveolar bone atrophy:ti,ab,kw (Word variations have been searched) & 61 \\
\hline$\# 3$ & alveolar bone resorption:ti,ab,kw (Word variations have been searched) & 309 \\
\hline$\# 4$ & narrow alveolar ridge:ti,ab,kw (Word variations have been searched) & 10 \\
\hline$\# 5$ & narrow ridge:ti,ab,kw (Word variations have been searched) & 17 \\
\hline$\# 6$ & atrophic ridge:ti,ab,kw (Word variations have been searched) & 57 \\
\hline$\# 7$ & bone deficiency:ti,ab,kw (Word variations have been searched) & 1074 \\
\hline$\# 8$ & compromised alveolar ridge:ti,ab,kw (Word variations have been searched) & 15 \\
\hline$\# 9$ & insufficient bone thickness:ti,ab,kw (Word variations have been searched) & 13 \\
\hline$\# 10$ & alveolar bone loss:ti,ab,kw (Word variations have been searched) & 1356 \\
\hline$\# 11$ & $\# 1$ or \#2 or \#3 or \#4 or \#5 or \#6 or \#7 or \#8 or \#9 or \#10 & 2571 \\
\hline$\# 12$ & MeSH descriptor: [Alveolar Ridge Augmentation] explode all trees & 297 \\
\hline$\# 13$ & MeSH descriptor: [Alveolar Bone Grafting] explode all trees & 12 \\
\hline$\# 14$ & alveolar ridge augmentation:ti,ab,kw (Word variations have been searched) & 351 \\
\hline$\# 15$ & alveolar bone grafting:ti,ab,kw (Word variations have been searched) & 557 \\
\hline$\# 16$ & ridge expansion:ti,ab,kw (Word variations have been searched) & 11 \\
\hline$\# 17$ & bone splitting:ti,ab,kw (Word variations have been searched) & 481 \\
\hline$\# 18$ & split crest:ti,ab,kw (Word variations have been searched) & 40 \\
\hline$\# 19$ & split expansion:ti,ab,kw (Word variations have been searched) & 34 \\
\hline$\# 20$ & bone expansion:ti,ab,kw (Word variations have been searched) & 315 \\
\hline$\# 21$ & bone expansion:ti,ab,kw (Word variations have been searched) & 315 \\
\hline$\# 22$ & ridge splitting:ti,ab,kw (Word variations have been searched) & 61 \\
\hline$\# 23$ & lateral ridge augmentation:ti,ab,kw (Word variations have been searched) & 40 \\
\hline$\# 24$ & lateral ridge augmentation:ti,ab,kw (Word variations have been searched) & 40 \\
\hline$\# 25$ & onlay bone:ti,ab,kw (Word variations have been searched) & 47 \\
\hline$\# 26$ & $\# 12$ or \#13 or \#14 or \#15 or \#16 or \#17 or \#18 or \#19 or \#20 or \#21 or \#22 or \#23 or \#24 or \#25 & 1433 \\
\hline$\# 27$ & $\# 11$ and \#26 & 588 \\
\hline
\end{tabular}

